\title{
STUDI AGAMA : GAGASAN KIM KNOTT TENTANG METODE SPASIAL ${ }^{1}$
}

\author{
Oleh : Heni Listiana \\ henilistiana@gmail.com \\ IAIN MADURA
}

\begin{abstract}
Abstrak
Metode spasial hadir untuke mengkaji keberadaan agama pada tempat-tempat non agama (sekuler). Isu-isu kontemporer yang dihadapi oleh politisi dan intelektual di negara-negara sekuler Eropa adalah hubungan antara sekularitas dan agama. ${ }^{2}$ Dalam konteks itu, Kim Knott berusaha menemukan bubungan antara keduanya, membongkar kebekuan antara keduanya yang sudah lama terjadi, dengan menggunakan metode spasial yang berasal dari ilmu-ilmu sosial dan budaya. Berangkat dari preposisi yang menyatakan ada hubungan antara agama, lokal dan masyarakat maka metode spasial, memosisikan agama sebagai ruang yang multidimensi, menjadikan tubuh sebagai peran sentral pembentuk ruang. Dalam ruang tubuh itu melekat agama yang menempati lokal dan masyarakat. Dengan kata lain, dalam diri orang beragama, agama ikut serta bersamanya kemanapun dia pergi dan dimanapun ia berada. Sebingga agama itu tidak hanya tampak pada tempat-tempat ibadah/agama saja.
\end{abstract}

\section{Kata Kunci : Metode Spasial, 'Suci’ dan Sakralisasi}

\section{A. Kontestasi Agama sabagai Kepercayaan dan Tradisi}

Dalam pergaulan dunia yang semakin terbuka dan transparan, orang tidak dapat dipersalahkan untuk melihat fenomena 'agama' secara aspektual, dimensional dan bahkan mungkin pendekatan multidimensional. Selain agama memang mempunyai doktrin teologis normatif, kepercayaan terhadap Tuhan $\left(\right.$ faith $^{3}$ - dan disitulah letak "bard core" dari pada keberagamaan manusia, orang dapat pula melihatnya sebagai "tradisi". Sedang tradisi sulit dipisahkan dari faktor "buman construction" yang semula dipengaruhi oleh perjalanan sejarah sosialekonomi-politik dan budaya yang amat panjang. Disamping itu, ekspresi atau ungkapan keberagamaan manusia,-yang semula bersifat-mendalam esoteris- secara eksternal, dapat berubah menjadi 'kelembagaan' agama dimana terlibat didalamnya pranata-pranata sosial yang kadang juga bersifat birokratis. Keberagamaan yang terekpresikan dalam bentuk kelembagaan eksternal ini bisa juga mengalami proses evolutif yang erat kaitannya dengan faktor ekonomi, sosial kemasyarakatan, militer, bahasa dan berbagai kecenderungan menusiawi lain yang tidak kalah kompleksnya dibandingkan dengan 'hard core' keberagamaan manusia. ${ }^{4}$

Kesulitan menjadikan agama sebagai bahan kajian ilmiah, mengikuti pendapat Wardenburgh, setidaknya berawal dari dua hal. Pertama, mengkaji berarti melakukan objektivasi, atau penjarakan terhadap objek kajiannya. Dalam kajian terhadap agama, objektivitas bukan hanya kepada pihak lain, tetapi juga pada diri sendiri. Setiap manusia akan memiliki keterlibatan

1. Kim Knott seorang professor studi agama di Uiversity of Leeds, professor of Religiuos and Secular Studies di Lancaster university, Inggris, penulis dan peneliti aktif di University of Leeds sejak 1976 yang tergabung dalam kelompok the community Religion Project. yang telah mengembangkan metodologi spasial bagi kontekstualisasi agama, menyelidiki isu keterlibatan agama dengan lembaga-lembaga sosial dan budaya lain dan "membongkar sekuler". Salah Satu karyanya "The Left Hand", buku yang menjelaskan pendekatan spasial dalam studi agama.

2. Kim Knott, Theoretical and Methodological Resources for Breaking Open the Secular and Exploring The Boundary between Religion and non Religion, Historia Religionum,2,2010, 115-33

3. Harun Nasution, Islam Ditinjau dari Berbagai Aspeknya (Jakarta: UI-Press,1985) 24

4. Amin Abdullah, "Studi Agama Normativitas atau Historisitas" (Yogyakarta: Pustaka Pelajar, 2011) hlm 9-10. 
dengan aspek keagamaan, dalam kontinum positif hingga negatif, dengan mengambil komitmen agama tertentu sampai menolaknya sama sekali. Jadi agama itu berhubungan dengan pengalaman batin yang subjectif dan personal. ${ }^{5}$ Untuk benar-benar mampu melakukan objektivasi terhadap kesadaran diri sendiri, tentu tidak hanya memerlukan keseriusan usaha, melainkan juga latihan dan ketekunan. Kedua, agama secara tradisional dipahami sebagai sesuatu yang suci, sakral dan agung. Menempatkan hal-hal semacam itu sebagai objek netral akan dianggap mereduksi, melecahkan atau bahkan merusak nilai tradisional agama. ${ }^{6}$

Studi agama merupakan salah studi yang memilik posisi penting dalam pengembangan keilmuan. Studi agama yang dimaksud lebih menjurus agama sebagai religious lives atau kehidupan keberagamaan yang berbeda jauh dengan theologi keagamaan. ${ }^{7}$ Bagaimana agama dapat dijelaskan secara ilmiah dengan menggunakan pendekatan spasial.

Pembahasan pendekatan spasial muncul dilatarbelakangi pemikiran para ahli yang menyatakan adanya hubungan antara agama, lokalitas dan komunitas yang terjadi pada akhir tahun 1990-an. Kim Knott pada tahun 2001 mulai mengembangkan metode ilmiah dengan pendekatan spasial untuk menganalisis lokasi agama dalam masyarakat barat kontemporer (sekuler) ${ }^{8}$. Knott melihat agama hanya berada pada suatu organisasi, pergerakan, masyarakat, tempat-tempat ibadah, atau juga dalam berbagai keyakinan dan praktik spiritual. Knott mulai meragukan adanya keterpisahan antara agama dan sekuler (Misalnya tempat: Sudut jalan, lapangan sekolah atau taman kota). Kemudian ia mencoba mencari jawaban dari pertanyaan besar tentang : benarkah tidak ada tempat untuk agama pada tempat-tempat yang sekuler itu?

\section{B. Teori dan Metode Spasial : Unsur-unsur Ruang}

Sebelum memahami tentang unsur-unsur ruang dan penerapan teori dan metode spasial dalam penelitian agama, harus diketahui terlebih dahulu tentang makna ruang itu sendiri.

... "Space" is a concept which allows us to talk, write and share ideas about an aspect of human and social experience, in this case the experience of our situatedness vis-à-vis the body, others and the world about us. Like "religion", it is a concept with a contested history. ${ }^{9}$ Dalam terjemahan bebas...."Ruang" adalah konsep yang memungkinkan kita untuk berbicara, menulis dan berbagi ide tentang aspek manusia dan pengalaman sosialnya. 'Pengalaman' itu, situasi yang vis-a-vis dengan tubuh kita, orang lain dan dunia tentang kita. Menurut Charles J. Adams pengalaman itu terdiri dari dua aspek yaitu inward experience dan outward behavioral. ${ }^{10}$ Sementara itu, dalam kajian insider dan outsider Knott mengkategorikan pengalaman itu menjadi dua yaitu pengalaman jauh (experience distance) dan pengalaman dekat (experience near). ${ }^{11}$ Seperti halnya "agama" menjadi konsep yang diperebutkan dengan sejarah.

Kajian ruang (space) berkaitan dengan tempat dan lokasi. Untuk memahami keterkaitan tersebut diperlukan dua hal. Pertama, teori-metode analisis tentang tempat dan lokasi sebagai

5. Muhaimin dkk, Kawasan dan Wawasan Studi Islam (Jakarta : Prenada Media,2005) hlm.30

6. Ahmad Norma Permata, Metodologi Studi Agama, (Yogyakarta: Pustaka Pelajar, 2000), hlm. 13-14.

7. Kim knott, Insider / outsider Perspectives dalam the Routledge Companion to the Study of religion, Edited by John R. Hinnels (London: Routledge Taylor and Fancis Group, 2005), hlm 243,

8 Misalnya hotel, restoran, pasar, sekolah, atau bahkan tempat prostitusi

9 Kim Knott. 'Spatial Theory and Method for Study of Religion'. The Finnis Society for the Study of Religion, Temenos Vol.41 No.2, 2005, 156

10 Inward experience adalah hal-hal yang bersifat batiniah dalam agama juga merupakan wilayah kesadaran perasaan dan tanggung jawab yang bersifat personal yang tidak dapat dikomunikasikan, dan hanya secara parsial dapat dimengerti orang lain. sedangkan outward behavioral adalah wujud luar atau manifestasi eksternal dari agama yang dapat dikomunikasikan. Charles J. Adams, Islamic Reliigious Tradition dalam Leonard Binder (ed). The Study of Middle East: Research and Scholarship in The Humanities and Social Sciences (New York:John Wiley \& Soons, 1976),33

11 Mereka yang dikategorikan dalam outsider adalah para pengamat (observer) yang memiliki pengalaman jauh (experience distance)dari agama yang dia kaji, atau orang lain yang menjadi audience dari kajian agama orang lain. Sementara insider diwakili oleh partisipan yang memiliki pengalaman dekat dari agamanya sendiri. 
proses sosio- spasial. Kedua, beberapa bentuk konseptualisasi agama (objek yang menjadi lokasi). Knott merasa tidak puas dalam memahami ruang hanya berdasarkan pada metode dan definisi yang telah ada. Hal yang menjadi perhatian dalam teori dan metode spasial ini adalah literatur tentang ruang suci, yang mengantarkan pada studi tentang agama dan lokalitas dan juga geografi agama.

Masalah utamanya adalah prediksi tentang agama sebagai suatu yang suci, aspek esensi dari pengalaman manusia, atau lanskap kondisi domain yang akan dikaji. Untuk memahaminya diperlukan pendekatan tempat dan lokasi yang tidak diambil dari agama atau teori dan metode suci. Tapi akan menarik jika memahami agama dengan pendekatan tempat dan lokasi itu berdasarkan pada teori ruang sosial dan budaya.

Pendekatan spasial Kim Knott berangkat dari teori grounded dan pendekatan induktif tentang agama dan lokalitas. Terinspirasi oleh teori tempat Martin Heiddeger, Maurice MerleauPonty to Yi-Fu Tuan, edward Cassey dan Cristopher Tilley serta para feminis dan kritik post-, modern tentang fenomenologi tempat, dan juga diskursus tentang pentingnya tempat oleh Gilian Rose dan Judy Tobler.

Ruang tidak hanya dimaknai sebagai abstrak dan geometri sebagaimana konsep Cartesian, tetapi lebih dipahami memiliki konfigurasi dengan waktu, sebagai sesuatu yang kompleks, dinamis dan relasional.

Dari teori spasial yang ada, Knott mengembangkan unsur-unsur pendekatan spasial untuk diterapkan pada masalah lokasi agama. Adapun unsur-unsur ruang tersebut adalah:12

\section{a. Tubuh sebagai Sumber dari Ruang}

Prinsip pertama dari pendekatan spasial ini terletak pada peran dasar tubuh dalam membangun pengalaman dan menjadi representasi dari ruang. ${ }^{13}$ Karena metafora spasial itu terjadi pada pusat kognisi, maka ketika berbicara tentang lingkungan, sifat masyarakat dan hubungannya, waktu dan kemajuan, dan tentang sesuatu yang suci pada saat itu terdapat perbedaan persepsi dari pertarungan hal-hal terkait dengan tiga dimensi ruang dan hubungannya dengan tubuh. Misalnya perbedaan atas-bawah, kanan-kiri dan depan-belakang. Perbedaan fitur yang melekat pada tubuh itu merupakan bagian-bagian yang kongruen. Hal ini berdasarkan pada: Pertama, perbedaan posisi, bagian, ruang daerah secara relasional dipahami sesuai dengan cara tubuh. Kedua, bagaimana orientasi tempat fisik dan mental yang bersifat bilateral-asimetris. Singkatnya, tubuh memungkinkan kita untuk mengalami dan membuat konsep hubungan antara hal-hal, tempat, orang (serta daerah), dan mengidentifikasi perbedaannya, karena dalam konstitusi tubuh itu sendiri terjadi perbedaan, dan perbedaan itu dapat ditemukan secara nyata". ${ }^{14}$

Menurut Lefebvre dan Foucault Sentralitas tubuh dalam kehidupan sosial dan tatanan budaya telah membentuk kita, dan keterlibatan kita didalamnya diakui dengan cara yang berbeda. Lefebvre menulis bahwa:

Seluruh ruang (sosial) yang dihasilkan oleh tubuh, meskipun telah bermetamorfosismisalnya tubuh telah melupakannya atau mungkin memisahkan diri secara radikal dari tubuh untuk menghilangkannya. Asal-usul dari suatu tatanan yang jauh dapat dipertanggungjawabkan hanya berdasarkan urutan yang paling dekat dengan kita - yaitu urutan tubuh. Di dalam tubuh sendiri sangat mempertimbangkan ruang, terjadi tingkatan secara berturut-turut dibentuk oleh indra. Ini merupakan bentuk dasar lapisan ruang sosial dan interkoneksi mereka.

12. Kim Knott. 'Spatial Theory and Method .... 156

13. Ibid, Kim Knott, 'Spatial Theory and Method for Study of Religion',157

14. Untuk pembahasan lebih lanjut esai Kant bagi tubuh, ruang dan tempat, lihat Casey (1997: 205-09) dan

JZ Smith (1987 : 27-28). Mark Johnson menyetujui analisis Kant tentang tubuh dan daerah ruang tetapi - dan di sini ia berbicara untuk sebagian besar sarjana akhir -modern - menolak kesimpulan Cartesian -nya tentang alasan, imajinasi dan tubuh (1987: xxvi - xxix ) . 
Jika tubuh menjadi tempat di mana tatanan budaya memainkan perannya, dan menjadi representasi agar dapat dikondisikan dan didisiplinkan olehnya. Lalu bagaimana gagasan tentang tubuh sebagai sumber persepsi dan konsepsi spasial, dan bagaimana hasil praktek budaya spasial dan politik yang memiliki hubungan dengan lokasi agama?

Mary Keller menjelaskan, tubuh menentukan kondisi yang memungkinkan terjadinya pengalaman untuk membentuk struktur pengetahuan. Dalam kaitan pembahasan tentan peran sentral tubuh sebagai sumber ruang dan agama, maka agama tentu harus bekerja dalam parameter ini, dan harus juga dibentuk atas dasar titik awal bio - spasial ini. Selain itu, tindakan menemukan agama memiliki prosedur yang sama seperti proses menemukan lokasi, harus berdasarkan pada kepekaan spasial kita sendiri yang diperoleh dengan cara diwujudkan dan berorientasi spasial, dan melalui kemampuan kita untuk berpikir dan mewakili hal-hal spasial.

Pengalaman agama sebagaian besar ada dalam bentuk kognitif eksploratif. Gagasan, konsep dan kepercayaan merupakan pernyataan formal yang membuat agama yang bersifat pribadi tersebut dapat disampaikan kepada orang lain. ${ }^{15}$ Secara sederhana dapat dipahami bahwa tubuh sebagai sumber ruang bermakna seseorang dapat melakukan penafsiran yang berkaitan dengan lingkungan, sifat dan pola hubungan masyarakat serta nilai kesakralan dalam masyarakat.

Jadi tubuh sebagai sumber dari ruang itu bermakna tubuh menentukan kondisi yang memungkinkan terjadinya pengalaman untuk membentuk struktur pengetahuan. Tubuh dibentuk untuk keperluan sosial.

\section{b. Dimensi Ruang}

Dimensi ruang itu meliputi fisik, mental dan sosial. Ruang bukan hanya dimensi mental atau konseptual, tapi juga dimaknai sebagai ide metafora dan membuka kesempatan bagi manusia untuk berimajinasi dan berekspresi guna terjadi perbedaan budaya, imajinasi, serta relasi sosial. Relasi sosial itulah yang merupakan dimensi sosial dari ruang. Bagi Lefebvre, hubungan sosial tidak memiliki eksistensi nyata kecuali melalui ruang. Semua hubungan baik terkait cinta-perjuangan, pertemuan langsung-elektronik merupakan dimensi spasial sosial. Apapun pandangan orang tentang ruang, baik Cartesian geometris atau postmodern global, ruang itu adalah relasional : hubungan jaringan antara titik-titik, antara tempat-tempat yang berbeda (atau bagian ruang), atau antara orang. ${ }^{16}$

Menurut Massey, ruang itu bermakna sosial dalam arti peran tubuh dibentuk untuk keperluan sosial. Konsepsi akhir abad ke-20 Lefebvre mendefinisikan ruang sebagai sesuatu yang diproduksi dan direproduksi oleh tindakan dan interaksi sosial manusia.

Agama-secara inheren sosial- juga harus ada dan mengekspresikan dirinya dalam dan melalui ruang. Selain itu, agama memainkan peran dalam produksi dan reproduksi ruang sosial. Komunitas agama transnasional, misalnya, mengakar dalam konteks nasional dan menyebar di berbagai tempat. Mereka mengekspresikan diri mereka melalui mobilitas pengikutnya, dalam media tulis dan dunia maya yang diberitakan, dan melalui tindakan spasial mereka, baik duniawi, ritual, performatif, atau bahkan teroris. Mereka juga menghasilkan ruang baru, misalnya, ruang diaspora - baik nyata dan imajinasi-, fisik dan sosial. Ruang bukan hanya dimensi fisik, mental dan sosial yang terbentuk tapi juga perkumpulan dinamis.

Ruang bukanlah wadah kosong atau tabula rasa di mana hal-hal lain ditempatkan pada apa yang terjadi pada mereka. Hal ini disebut sebagai multi-dimensi ruang. Secara konseptual "ruang" menurut Lawson disebut sebagai penutupan senyawa linguistik di mana hal-hal lain (lebih tepat konsep atau nama mereka ) dibawa bersama-sama, berkumpul atau

15. Brian Moris, “Antropologi Agama, Kritik Teori-teori Agama Kontemporer".(terjemahan Imam Khoiri) 
berkonfigurasi. ${ }^{17}$ Berbagai kemungkinan seperti proses pengumpulan atau konfigurasi memang salah satu cara di mana gagasan ruang bisa dikatakan tetap terbuka meskipun terlihat tertutup. Tapi ruang memiliki sifat lain yang juga tetap terbuka dan dinamis. Dimensi ruang meliputi individu dan sosial serta perbedaan budaya membaur menjadi satu kesatuan. Perbedaan tempat akan berpengaruh pada budaya dan disitu terdapat reproduksi budaya dan agama baru. ${ }^{18}$

\section{c. Sifat Ruang}

Sifat ruang meliputi konfigurasi, simultasitas, ekstensi dan kekuasaan. Hal ini merujuk pada refleksi Foucault tentang "epoch of space". Dimana ruang itu memiliki epoch yang simultan: epoch kesejajaran, epoch dari dekat dan jauh, dari side-by-side, dan ekstensi. Pengalaman kita tentang dunia dikembangkan melalui waktu daripada jaringan yang menghubungkan antar hal dan bersinggungan dengan gulungan itu sendiri. Epoch kita adalah salah satu di mana ruang diperlukan bagi kita untuk membentuk hubungan antar situs. Gagasan ruang kontemporer sebagai bentuk hubungan sinkronis dan ekstensi diakronis. Massey mengilustrasikan simultanitas ruang itu pada Jalan Raya Kilburn London, dimana terjadi kompleksitas internal dan keragaman serta interkoneksi dinamis dengan situs global lainnya. Jika mengambil contoh pada Jalan Raya Kilburn, maka dapat ditemukan ada jaringan kontemporer yang menjadi -pasar ekonomi global, hubungan transnasional penghuni dan pengunjungnya, bahasa, agama dan budaya konsumsi bersama dengan koneksi global merekadidalamnya juga berisi sejarah sebagai sesuatu yang selalu hadir sebagai "etimologi lokasi". ${ }^{19}$

Tempat tertentu misalnya-katedral Romawi Perancis, Sikh Inggris Gurdwara dulu merupakan sebuah pabrik atau sekolah - terdiri dari dimensi ruang sosial, fisik dan sejarah budaya di dalamnya, berbagai tahapan dalam lapisan perkembangannya dilalui dan kadang-kadang terlibat secara instrumental antara satu dengan lainnya sepanjang perjalanannya.

Gereja-gereja dan tempat-tempat ibadah lain, seperti tempat-tempat simbolis, adalah salah satu sarana ide-ide keagamaan tentang Tuhan, komunitas manusia, dan proses ritual yang memproduksi ruang suci dengan memberikan kehadiran material. Kekuatan ideologi bukan menjadi satu-satunya cara di mana kekuasaan terjadi dalam ruang, tapi kinerja resistensi dan subversi juga memiliki konsekuensi spasial. Misalnya demonstrasi di London awal tahun 2003 menentang perang di Irak, dimana organisasi politik keagamaan sekuler adalah bukti terjadinya transformasi ide kepada tubuh partisipan yang turun ke jalan dan direproduksi oleh kota-kota lain yang tidak terhitung jumlahnya. Seperti diberitakan di halaman pers dunia, dan situs elektronik. Selanjutnya, mereka memasuki ruang kesadaran, tidak hanya dari para demonstran, tapi orang-orang yang mendukung perang, sebagai pengingat dari kekuatan perlawanan.

\section{d. Aspek Ruang}

Aspek ruang (Lefebvre) itu meliputi tiga hal yang saling terkait dimana ruang itu dipahami, dirasakan dan ditempati oleh orang-orang. ${ }^{20}$ Aspek pertama adalah "praktik spasial" dimana ruang secara umum digunakan, dirasakan orang-orang dalam kehidupannya seharihari. Agama, hadir secara fisik dalam tatanan sosial, dan dalam bentuk budaya sebagai konsekuensi dari praktik sosial, atribut makna seperti praktek yang memiliki karakter agama. Aspek kedua, Representasi spasial itu diproduksi oleh perencana, arsitek, dan sarjana. Ruang itu menjadi ekspresi ideologi, secara khusus dari tatanan yang dominan. Pada zaman sekuler

17. Heidegger yang memperkenalkan gagasan bahwa tempat " mengumpulkan " atau memegang sesuatu bersama-sama ( versammlung ) dalam esainya tentang " Building, Dwelling, Thinking " (1993) .

18. Ibid, Kim Knott, 'Spatial Theory and Method for Study of Religion',160

19. Ibid, Kim Knott, 'Spatial Theory and Method for Study of Religion',161

20. Ibid, Kim Knott, 'Spatial Theory and Method for Study of Religion',163 
modern, orientasi tentang dunia, terdapat pada jejak agama pada periode awal. Di Inggris, gothic abad pertengahan, atau bangunan neo-ghotic abad kesembilan belas (memiliki dua karakter 'agama' dan 'non-agama'), yang berwujud pada bangunan kaca, baja, dan menara blok.

Dalam upacara-upacara kenegaraan, kemasyarakatan dan wacana Hak Asasi Manusia (HAM) sebagai contoh ruang sosial dan mental kontemporer dapat menjadi representasi agenda pluralis sekuler dan para agamawan. Aspek ketiga adalah 'Space of Representasi' itu hidup dalam imajinasi dan simbol. Misalnya artis, penulis, pemain, inovator ritual, dan simbol agama, yang menggunakan imajinasi dan simbol digunakan dalam ruang fisik, dalam rangka menolak kekuatan dominan, rezim, atau diskursus. Bagi Lafebvre ruang yang hidup itu menjadi asosiasi perlawanan bawah tanah -karnaval politik, misalnya agama persuasif yang dilakukan oleh Christine Chivaallon, dalam ruang akunnya yang melahirkan Black Christian experience in England. Ide dan praktik agama Karibia Afrika merupakan bentuk ruang yang berfungsi untuk mendekonstruksi tatanan rasial tertulis dalam ruang di Inggris dan menggantinya dengan ruang representasi yang lebih berdimensi mental daripada material, yang bebas dari kategorisasi ini.

\section{e. Dinamika Ruang}

Dinamika ruang adalah sangat terkait dengan kekuasaan, sejarah dan waktu ${ }^{21}$ dalam artian agama akan selalu terkait dan dipengaruhi oleh kekuasaan, sejarah dan waktu. Kondisi simultanitas dan cara di mana ia dialami dan diwakili. Tidak lagi ruang dilihat sebagai wadah pasif atau latar belakang bagi aktivitas manusia. Ruang benar-benar terikat dalam perwujudan dan praktek sehari-hari, pengetahuan dan wacana, dan dalam proses produksi dan reproduksi, dan akibatnya ia terperangkap dalam agama seperti di daerah lain dari kehidupan sosial dan budaya.

Membuka "ruang" untuk pengawasan yang lebih ketat dan mengidentifikasi beberapa elemen penyusunnya merupakan tahap penting dalam proses mengubah teori ke dalam metodologi yang bisa diterapkan dalam berbagai kasus. Sebelum kembali ke pertanyaan metodologi spasial, pertama kita harus mempertimbangkan apakah studi mengenai agama dapat menawarkan sesuatu tambahan untuk proses ini.

\section{Permasalahan (Kegelisahan Akademik)}

Kegelisahan Knott mengacu pada artikel 'Spatial Theory and Method for Study of Religion' ini muncul untuk mempertanyakan bagaimana posisi agama pada tempat-tempat sekuler. Benarkah tidak ada agama pada tempat-tempat yang sekuler?. Sementara agama diyakini hanya berada pada tempat-tempat ibadah dan organisasi keagamaan, pada gerakan baru keagamaan, dan hanya berada pada keyakinan dan praktek "spiritual" belaka. Jadi belum jelas sejauh mana agama itu hadir atau melakat pada tempat-tempat yang seolah-olah sekuler, seperti sekolah, rumah sakit, taman bermain dan lain sebagainya. ${ }^{22}$

\section{Pentingnya Topik Penelitian}

Agama itu menempati ruang tertentu, berkembang dan menyebar sesuai dengan produksi-reproduksi ruang yang dilakukan oleh pengikut dan pemeluknya. Kajian ruang selama ini hanya menjadi kajian sosial dan budaya. Dengan menarik pengertian dari Henri Lefenvre tentang dimensi ruang maka ada keterkaitan antara ruang dengan agama. Jika agama dipahami dalam konteks ruang, maka agama hanya bisa berkembang dan menyebar dalam ruang-ruang

21. Ibid, Kim Knott, 'Spatial Theory and Method for Study of Religion', hlm.166

22. Ibid, Kim Knott, 'Spatial Theory and Method for Study of Religion', hIm.153 
yang telah di buat oleh tubuh sebagai sumber ruang. Dalam tubuh sendiri sudah menggambarkan adanya bio-spasial (ruang hidup). Demikian juga agama akan tetap hidup selama ruang sosial itu ada. Untuk memahami tempat-tempat yang jauh dapat dilakukan dengan memahami tempat yang dekat dengan kita. Dalam kaitan ini penting untuk memahami agama dari sudut pandang lokal. Untuk membedah posisi agama dalam lokal dan komunitas tertentu dengan memahami kerja metode ruang. Tempat-tempat yang menjadi simbol agama, harus dipahami sebagai ruang yang diciptakan oleh manusia. Suci dan sakralisasi itu adalah buatan manusia.

\section{Hasil Penelitian Terdahulu}

Kim knott telah meneliti karya terdahulu sebelum memberikan tawaran baru dalam studi agama diantaranya Martin Heiddeger, Maurice Merleau-Ponty, edward Cassey dan Cristopher Tilley, de carteau, Foucault, Carette, Lakoff dan Johnson, Lefebvre, Mary Keller, Massey, Harvey, Shields, Soja, Merrifield dan Elden dan lainnya. Berangkat dari karya-karya ini, Knott mencoba memberikan tawaran pemikiran terhadap studi agama. Kajian utamanya adalah menggunakan teori spasial (berangkat dari disiplin ilmu sosial-budaya) untuk memahami agama dari metode spasial yang berbasis pada lokalitas, guna mencari posisi agama dalam lokal masyarakat yang bersifat global.

\section{Tawaran Kim knott}

Berawal dari gagasan ruang dari disiplin ilmu sosial-budaya. Knott mencoba menggunakan alat analisa spasial untuk membedah agama pada lokal masyarakat. Pendekatan berbasis lokalitas berusaha untuk menyambung kembali agama dengan bidang sosial dan budaya lainnya dan untuk mengenali dampak dari kekhususan lokal pada kehidupan religius suatu daerah. ${ }^{23}$

Lokasi agama pada tempat-tempat sekuler :

\begin{tabular}{|c|c|c|c|c|}
\hline Tempat & Contoh & Pandangan lama & \multicolumn{2}{|c|}{ Tawaran Kim Knott } \\
\hline Agama & Gereja, Masjid, organisasi & Agama $=$ tempat agama & \multicolumn{2}{|c|}{ Tempat/Lokal } \\
\hline & & & $\downarrow$ & $\downarrow$ \\
\hline \multirow[t]{5}{*}{ Sekuler } & \multirow{5}{*}{$\begin{array}{l}\text { Pasar, Hotel, Sekolah, } \\
\text { Pasar, dan lain sebagainya }\end{array}$} & \multirow[t]{5}{*}{ Agama $\neq$ tempat sekuler } & & Tempat sekuler \\
\hline & & & $\downarrow$ & $\downarrow$ \\
\hline & & & Simbol agama & Metode Spasia \\
\hline & & & \multirow[t]{2}{*}{$\downarrow$} & $\downarrow$ \\
\hline & & & & Asama \\
\hline
\end{tabular}

23. Kim Knott, "From locality to location and back again: A spatial journey in the study of religion" Published in Religion 39:2, 2009, pp. 154-60, 


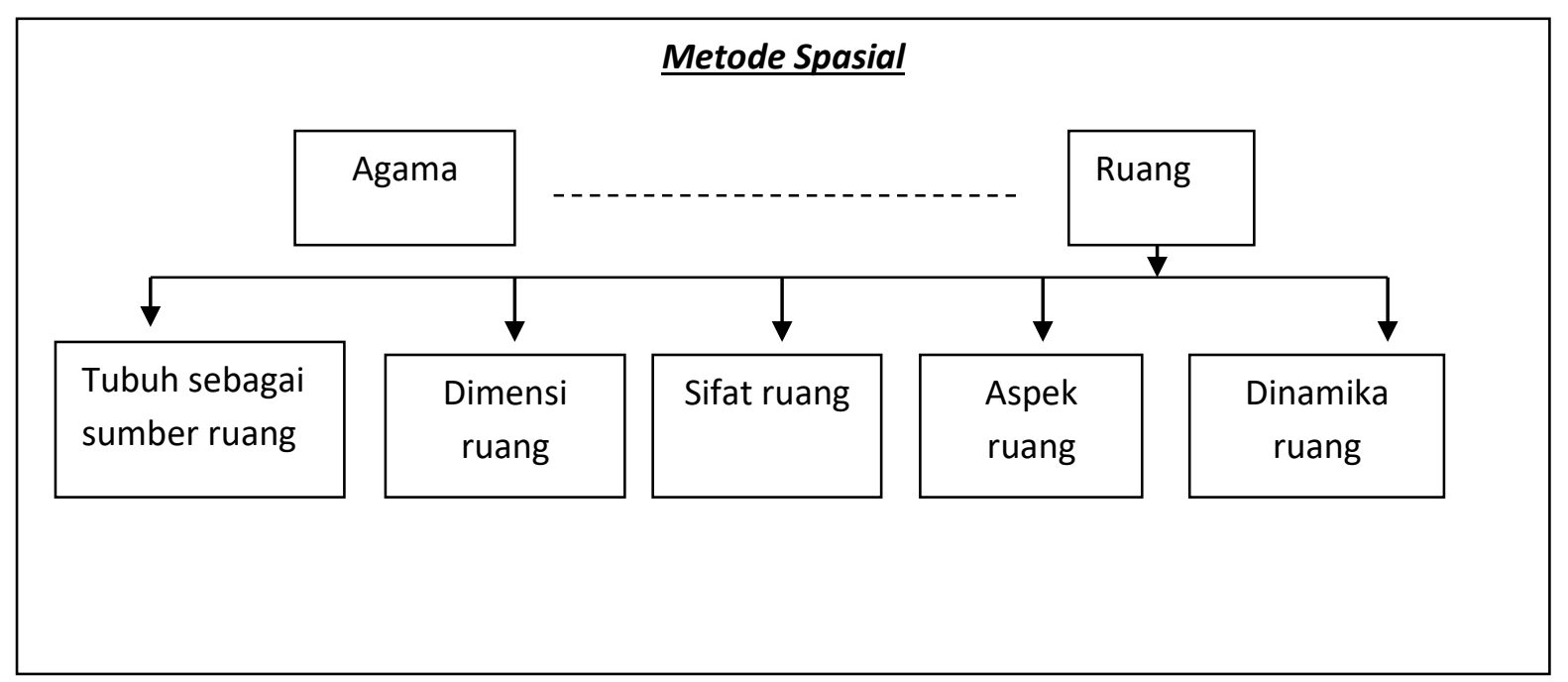

Jika kita ingin menguji bibliografi yang ditulis oleh ahli geografi agama, maka umumnya kelompok akademik menyimpulkan bahwa kontribusi sarjana diluar disiplin geografi kecil. Sampai sekitar tahun 1990-an belum ada upaya untuk mengatasi jarak perbedaan antara geografi dan agama hingga temukan pemahaman pendekatan yang berbeda.

Sebuah harapan muncul dari diskusi tentang ruang suci oleh Paul Wheatley atau Jonathan Z. Smith, dua jurnal geografi agama langsung direview dengan menggunakan berbagai disiplin dan pendekatan. Kong (2001) dan Holloway dan Vallin (2002) mulai mengembangkan agenda resiprokal baru yang lebih sesuai dengan tren studi sosial-budaya kontemporer dengan ketertarikan para sarjana. Kontribusi mereka sangat besar dalam meletakkan dasar geografi agama, untuk membahas masalah empirik yang lebih luas dari pada berorientasi pada teori atau metode saja.

\section{a. 'Suci'atan 'sacred'}

Tanpa diragukan lagi fokus spasial dalam studi agama, dan kontribusi para sarjana pada disiplin studi agama yang sangat besar, tentang ruang dan suci. Van der Leeuw melakukan inventarisasi situs suci dari Religion in Essence and Manifestation. ${ }^{24}$ Seri tentang homologi - rumah, kui, pemukiman, tempat ziarah, tubuh manusia- dan hubungan sinekdot - perapian, altar, kudus, suci dan hati - secara formatif menjadi istilah kunci dalam diskusi ilmiah tentang puisi yang sakral. Berdasarkan catatan Chidester dan Linenthal, terlepas dari ceritanya tentang kehadiran suci, van der Leeuw mengakui " bahwa posisi tempat suci adalah tindakan politik, baik posisi yang terlibat sendiri, seleksi, orientasi, pembatasan, atau penaklukan". Selain itu, ia menyadari bahwa tempat suci itu kuat karena itu disesuaikan, memiliki dan dimiliki". Jadi, sementara Chidester dan Linenthal mengakui bahwa para ahli agama terutama telah memperhatikan van der Leeuw melalui tipologi fenomenologis situs suci, mereka berpendapat bahwa ia juga meletakkan dasar bagi diskusi selanjutnya dari situs konstruksi dan politik tersebut. Fokus mereka sendiri pada kontestasi, dalam kaitannya dengan tiga domain - alam, buatan dan mitos yang tumpang dari interpretasi ruang sebagai sesuatu yang suci.

Puisi Eliade tentang ruang sakral telah memberikan kerangka acuan bagi semua sarjana geografi sakral berikutnya, baik pengikut maupun kritikus. Aksiomanya - ruang suci sebagai bagian terpisah dari urutan, ruang profan, sebagai 'pusat ' atau sumbu mundi melalui komunikasi 
antara domain yang berbeda adalah mungkin, dan sebagai manifestasi dari 'Real' ( atau hierophany) - telah menjadi dasar untuk artikulasi ilmiah tentang makna dan kekuatan suci dalam ruang dan waktu. Mereka juga telah menjadi sarana bagi sarjana berikutnya yang telah pindah pembahasan 'ruang suci ' dari akarnya dalam konsepsi ontologis yang kudus atau suci untuk interogasi kritis terhadap proses manusia yang terlibat dalam membuat ruang 'sakral'-dalam memproduksi, membangun, bertarung, dan membayangkan situs posisi , nilai dan makna yang dimiliki oleh pencipta mereka, pemilik dan para pengikutnya untuk menjadi sesutau yang non-negosiasi dengan kategori khusus dan berbeda.

Berlanjut kepada gagasan tentang peta oleh Jonathan Z. Smith memberikan dua kontribusi untuk teori dan metode spasial. Pertama, dia memperkenalkan terminologi spasial, berdasarkan pada proposinya "peta bukan teritori" berdasarkan konsep meta-spasial (peta) dari konteks geografi (teritori) dan menerapkannya dalam satu kosmologi yang berbeda dalam melihat dan menganalisa dengan cara yang berbeda tentang pandangan dunia (worldview). Kedua, tempat itu bermakna lebih dari ruang alami dan material. Ruang hidup petama kali dan selanjutnya berada dalam hati dan pikiran yang kemudian disebut sebagai organisasi sosial. Ruang fisik, baik menyangkut yang "suci" atau profan merupakan bentuk dasar kosmologi dan sosial membangun peta dunia.

Karya To Take Place berusaha untuk menjawab pertanyaan dasar, bagaimana jika ruang tidak resipien (terjadi begitu saja) tetapi merupakan proyek ciptaan manusia? Bagaimana jika tempat itu merupakan produk intelektual aktif bukan wadah yang pasif?. Manusia tidak ditempatkan, mereka menciptakan ruang itu menjadi ada. Berdasarkan pada proposisi ini, berkaitan dengan agama-ruang suci itu tidak hadir begitu saja tetapi ia diciptakan - melalui ritual. Ritual merupakan proses kreatif dimana orang-orang memaknai dunia supaya mereka bisa tinggal didalamnya. Ritual itu bukan...respon kepada yang suci, tetapi sesuatu atau seseorang dibuat suci oleh ritual. Chindester dan Linenthal mendefisikan suci itu adalah situasional, relasional dan berfrekuensi, jika tidak secara inherent, diperebutkan.....suatu bi-produk dari pekerjaan sakralisasi. Tetapi mereka juga memberikan catatan bahwa proses ini lebih baik dipahami sebagai perwujudan praktik spasial yang terpisah. Tempat yang suci merupakan hasil dari sakralisasi, tetapi sakralisasi sendiri, bergantung kepada ruang "teknik tubuh".

\section{b. Sakralisasi}

Dual spasial (Veikko Anttonen), untuk siapa ruang itu- merujuk kepada tubuh dan teritori- apakah hanya sebagai produk sakralisasi atau merupakan aspek proses (dalam bentuk praktik spasial). Ini adalah batas kategori 'suci'. Menurut Anttonen, tubuh dan teritori adalah struktur konseptual yang mendasar untuk diskursus dan praktek yang berkaitan dengan yang suci. Mereka bukan hanya berada pada domain pengalaman yang memiliki makna sosial sebagai tafsir simbolik. Tetapi karena pikiran/tubuh adalah interaksi kita-yang diorganisasi secara kognitif pada level prekonseptual, maka nilai yang berguna tentang sesuatu yang "suci" sebagai batas kategori, bukan pondasi alami, tetapi juga terjadi inter-relasi atau co-ektensif entitas yang dibatasi. Anttonen menetapkan pentingnya pembentukan kategori kognitif dan aplikasi budaya dengan istilah "inside" dan "outside" dan ruang ketiga diantara mereka adalah batas (boundary) ${ }^{25}$

Tubuh manusia memiliki dua sisi ini inside dan outside, yang kemudian menjadi coextensif dengan teritori inside dan tinggal didalamnya. Batas diantara tubuh dan teritori- pemisah antara inside tubuh dari outside teritori menjadi penanda budaya yang tergantung pada pembuat kognitif untuk membedakan entitas pada basis nilai mereka dan untuk menetapkan aturan keterlibatan dan transformasi mereka:

Manusia memiliki sifat disposisional untuk berinvestasi pada batas ini misalnya dalam kategori waktu, ruang dan tubuh manusia dengan nilai referensial khusus dan potensi inferensial. Kapasitas ini diaktifkan di tempat-tempat terpisah sebagai suci. 
"Suci" merupakan kategori batas yang "memisahkan" antara tubuh dan teritori, laki-laki dan perempuan, orang dan binatang. Juga batas "mengikat" secara bersama-sama. Secara umum batas adalah situasi ketika fokus komunitas atau pergantian orang dari inside menjadi outside atau vise versa. Dan ritual adalah prinsip proses budaya untuk mengaturnya.

Anttonen telah mencatat, " pemaparan etnografis, genre cerita rakyat, serta teks-teks agama, kehadiran eksplisit atau implisit merupakan referensi untuk membatasi ruang dan teritori seperti tubuh manusia sebagai lokasi utama dari diskursus suci.

"Suci" -tindakan sakralisasi- menjadi lebih terbuka untuk melakukan verifikasi empiris ketika mereka berteori atas dasar tindakan, peristiwa dan niat dari agen budaya dalam konteks tertentu karena mereka membuat perbedaan antara ruang, tanda untuk keperluan tertentu, membuat batas-batas terlihat dan tak terlihat, dan menetapkan konvensi budaya perilaku pada batas-batas itu.

Pendekatan teoritis spasial dapat memberikan sumber yang kuat untuk menguji, khususnya, tempat-tempat yang seolah-olah non - agama atau sekuler tapi yang memiliki sakralitas yang tetap dikaitkan.

Situs kegiatan spiritual dalam beberapa indra generik atau universal dan di mana tidak adanya simbol-simbol keagamaan eksplisit atau arsitektur yang berhubungan dengan satu komunitas iman tunggal, memungkinkan ruang bagi masyarakat untuk mengeksplorasi sendiri keyakinan mereka yang terkadang kacau (atau kekurangan mereka). Orang dapat melakukan penafsiran secara mandiri. Seperti ruang yang sangat cocok untuk kebutuhan peningkatan jumlah orang yang lupa ( atau yang mungkin belum pernah dikenal) protokol mengunjungi bangunan keagamaan.

Pemeriksaan Gilliat-Ray dari afinitas antara ruang sakral un-konvensional dan kebutuhan orang-orang yang mungkin melewatinya. Menimbulkan pertanyaan tentang kedua sifat dan fungsi ruang sakral sekuler dan proses sakralisasi pada akhir - modernitas yang membentuk konteks baru untuk perdebatan dalam studi agama di ruang suci.

Jadi pada tempat - tempat atau lokal non-agama. Ternyata ada agama disana yang hidup dalam ruang tubuh manusia sebagai pengikutnya. Dalam pikiran manusialah yang menjadikan adanya batas dalam memandang tempat-tempat non agama tersebut.

Apa kontribusi studi agama pada teori sosial budaya yang terdahulu? Berdasar kepada fokus agama dan suci, maka akan terjadi pengulangan klaim utama. Maka ide ruang sebaiknya dipahami sebagai multi-dimensi. Seperti yang diungkapkan oleh JZ.Smith tentang makna sosial tempat dan menempati. Chindester dan Linenthal membahas tentang kosmologi dan mitos ruang. Ruang itu produksi dan reproduksi oleh Lefebvre menguatkan kepada produk dan persaingan ruang suci. Sementara kosmologi peta oleh Smith menunjukkan ide yang tidak sama dari teori Lefebvre tentang uji ruang itu dipahami, dirasakan dan ditempati oleh orang-orang.

Para ahli agama yang telah membahas masalah ruang sudah melewati beberapa teori grounded seperti teori awal. Kontribusi berharga yang diberikan sarjana agama pad ruang adalah tentang sakralisasi dan suci, yang beum ditemukan oleh komunitas diluar agama. JZ Smith berpendapat bahwa tempat tersebut diwujudkan melalui ritual: sakralisasi menghasilkan tempat bermakna, " Ruang suci". Hal ini sah untuk menanyakan apakah ada diskusi ilmiah ruang produksi sekarang akan lengkap tanpa pertimbangan ruang suci. Selanjutnya, Anttonen telah menyarankan bahwa aktivitas suci ini keputusan adalah bergantung pada perwujudan manusia dan lokasi sosio- spasial yang bersama-sama memberikan dasar bagi kategorisasi kognitif dan munculnya "suci " sebagai batas kategori. Antara mereka, Anttonen dan Smith telah membuat kasus untuk tak terpisahkan pengertian ruang dan sakral. Tapi apakah perkembangan teori spasial itu menjadi marjinal karena mereka fokus pada sacralitas dan produksi ruang sakral? Teori ini mampu untuk bekerja mengenali sentralitas proses sakralisasi di semua masyarakat, termasuk yang sekuler, dan dalam hubungannya dengan berbagai keprihatinan dan kepentingan sosial, budaya dan ideologi, termasuk juga agama. 
Akhirnya, semua istilah yang dimunculkan dalam metode spasial memerlukan serangkaian analisis, pemilihan objek penelitian seseorang atau tempat dari perspektif ini. Diawali dengan tubuh, dimensi dan sebagainya. Istilah-istilah itu bentuk singkat, jadi, untuk analisis penuh itu perlu menjadi fasih dengan latar belakang teoritis pembahasannya. Hal ini tidak cukup, misalnya, hanya memiliki " tubuh " dalam pikiran ketika berpikir tentang suatu obyek atau tempat, kita perlu kesadaran dari cara di mana konsepsi spasial telah muncul dari perwujudan kita, bagaimana ruang tertentu atau tempat yang berasal dari tubuh dan lokasi mereka dalam ruang, dan cara di mana tubuh sendiri adalah sebuah ruang yang dihasilkan ditindaklanjuti dan diinformasikan oleh berbagai perintah dan rezim. Untuk menggunakan contoh lain, sulit untuk melihat bagaimana orang bisa melanjutkan menganalisis suatu objek atau tempat dari perspektif aspek ruang tanpa kesadaran argumen teoritis yang mendukung ide tentang dirasakan, dipahami dan hidup ruang. Keterlibatan analitis teoritis dan komitmen pada metodologi spasial ini membutuhkan waktu dan usaha yang cukup banyak untuk menghasilkan sesuatu yang produktif. Tidak perlu semua elemen itu diterapkan misalnya hanya mengambil pada dimensi, sifat atau dinamikanya saja.

Meskipun awalnya pendekatan ini dirancang untuk tujuan mencari agama di tempattempat tampaknya non - agama atau sekuler, tapi pendekatan ini dapat digunakan untuk penyelidikan intensif dari setiap objek atau tempat (atau representasi daripadanya). Untuk studi agama metodologi ini menawarkan pendekatan baru sesuai dengan waktu sejauh memungkinkan para sarjana untuk terlibat dengan tema penting dalam sosial kontemporer dan teori budaya.

\section{Ruang Lingkup dan Istilah kunci}

Dalam pembahasan tentang metode spasial ini istilah yang harus dipahami adalah tubuh sebagai sumber dari ruang, dimensi ruang, sifat-sifat ruang, aspek ruang dan dinamikanya. Bagaimana agama itu dianggap sebagai ruang suci dan bagaimana pula proses sakralisasi pada ruang suci itu terjadi. Jadi kata kuncinya adalah : ruang, suci dan sakralisasi.

\section{Kebaharuan (contribution of knowledge)}

Adapun kontribusi Kim Knott terhadap pengetahuan (knowladge) antara lain: pertama, mempertemukan antara ilmu-ilmu sosial-budaya dengan studi agama. Kedua, penggunaan analisa metode spasial dalam menentukan posisi agama pada tempat sekuler. Ketiga, menunjukkan bagaimana kerja teori spasial terhadap ruang suci dan proses sakralisasi Keempat, Pendekatan spasial dengan mengamati lokal terdekat dengan diri kita, dapat menemukan agama di tempattempat yang tidak terbatas.

Tawaran Kim Knott

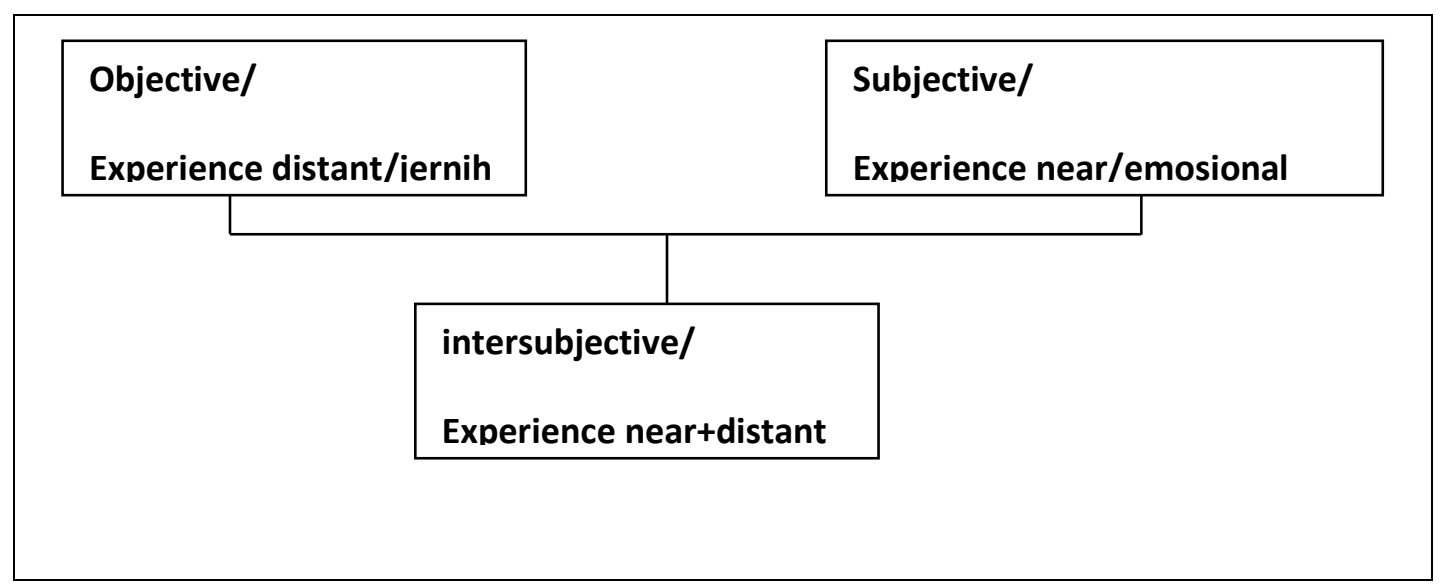


Insider dan Outsider

\begin{tabular}{|c|c|c|c|}
\hline OUTSIDER & & & \\
\hline Complete & Observer as & Partisipan as & Complete \\
\hline
\end{tabular}

Space (Ruang)

-Rapprochement(Saling mendekat)
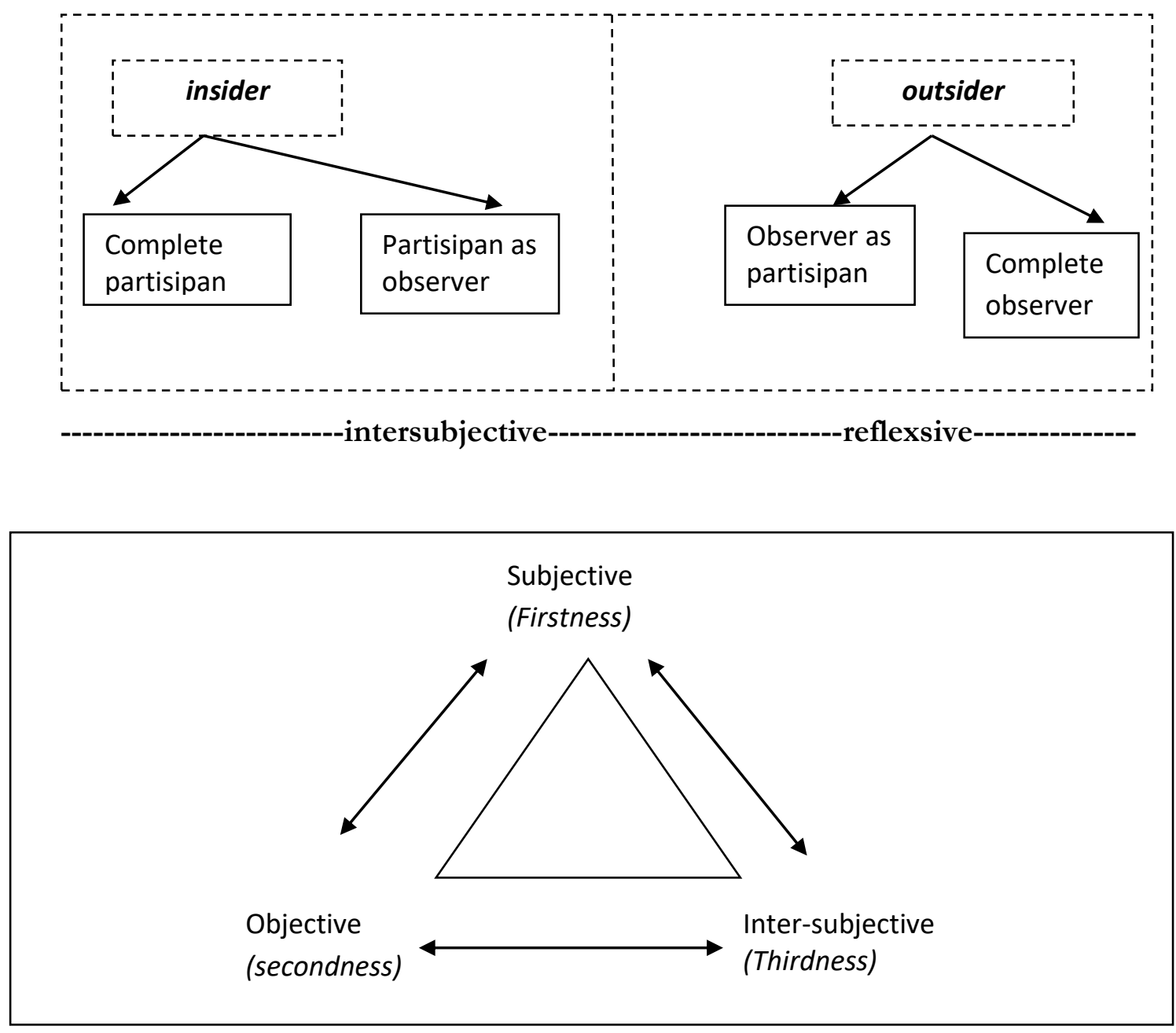

Pendekatan rappochement merupakan upaya solutif intersubjetive guna memosikan peneliti pada margin of apreciation sebagai tapal batas (border line) antara insider dan outsider. Dalam pendekatan tersebut, tidak ada tuntutan untuk meleburkan diri dalam dua pribadi yang berbeda, namun dari keduanya masih dimungkinkan untuk dicari titik temu meski kecil. dan jika dikomparasi tolok ukur standpoint masing-masing unsur di atas, dapat dijabarkan dalam bagan berikut ini: 


\begin{tabular}{|l|l|l|}
\hline SUBJECTIVE & OBJECTIVE & INTER-SUBJECTIVE \\
\hline The world of faith & The world of scholarship & The world of rappochement \\
\hline Beliefe & Impartialitas (clarification) & Dialogic of ideas \\
\hline Feideist/theistic & Objective rationality & Reflexity \\
\hline Emic/insider & Etic/outsider & Circular \\
\hline
\end{tabular}

\section{Sistematika}

Penulisan Kim Knott tentang Spatial Theory and Method for Study of Religion diawali dengan hal-hal yang membuatnya gelisah untuk mencari agama pada masyarakat Barat Kontemporer yang sekuler, kemudian dilanjutkan dengan sumber dalam pendekatan spasial berdasarkan teori sosial dan budaya, yaitu bagaimana memaknai tentang ruang bukan hanya dari dimensi fisik, dan mental belaka tetapi juga dengan dimensi sosialnya, pemaknaan manusia terhadap pengalamanya. Kemudian dia menawarkan pandangan baru tentang ruang dengan mengalisis adanya ruang suci dan sakralisasi dalam agama, dan diakhiri dengan aplikasi, kekuatan dan kelemahan metode spasial dalam pengembangan studi agama.

\section{Refleksi akhir}

Untuk mencari agama pada tempat-tempat non agama atau sekuler. Diperlukan pendekatan dan metode baru dalam mencari keterkaitannya. Metode spasial ini berusaha mendekati tempat-tempat non agama itu dengan teori ruang. Ruang tidak hanya dimaknai sebagai yang alami, tapi ruang itu dibuat. Manusia, juga termasuk ruang, itu sendiri melekat padanya pengalaman, pengetahuan berkaitan dengan agama. Artinya dimanapun ada manusia maka disana ada agama. Agama melekat sebagai identitas seseorang, hidup dan menempati ruang-ruang dan menyebar.

Dalam konteks studi Islam, metode spasial ini sangat berguna untu menganalisa hubungan agama dengan konteks sosial, budaya, hukum, pendidikan dan lain sebagainya. Menempatkan agama sebagai inside kemudian konteks diluar agama sebagai outside, dan batas sucinya adalah peneliti agama itu sendiri. Sehingga akan muncul pemahaman baru tentang kontekstualisasi agama. 


\section{Daftar Pustaka}

Abdullah, Amin dkk. 2000 Antalogi Studi Islam: Teori dan Metodologi, Yogyakarta: Sunan Kalijaga press

Abdullah, Amin. 2011 Studi Agama: Normativitas atau historisitas, Yogyakarta: Pustaka pelajar

Kim Knott. 2005.' Spatial Theory and Method for Study of Religion'. The Finnis Society for the Study of Religion, Temenos Vol.41 No.2

Knott, Kim. 2005. Insider / outsider Perspectives dalam the Routledge Companion to the Study of religion, Edited by John R. Hinnels .London: Routledge Taylor and Fancis Group,

Knott, Kim. 2010. Theoretical and Methodological Resources for Breaking Open the Secular and Exploring The Boundary between Religion and non Religion, Historia Religionum,2,

Knott. Kim, 2009. "From locality to location and back again: A spatial journey in the study of religion" Published in Religion 39:2,

Moris, Brian. 2003. Antropologi Agama, Kritik Teori-teori Agama Kontemporer".terjemahan Imam Khoiri. Yogyakarta:Ak Group, Cet.I,

Muhaimin dkk. 2005. Kawasan dan Wawasan Studi Islam. Jakarta : Prenada Media.

Nasution, Harun. 1985. Islam Ditinjau dari Berbagai Aspeknya. Jakarta: UI-Press.

Permata, Ahmad Norma. 2000. Metodologi Studi Agama. Yogyakarta: Pustaka Pelajar.

. Charles J. Adams, Islamic Reliigious Tradition dalam Leonard Binder (ed). The Study of Middle East: Research and Scholarship in The Humanities and Social Sciences (New York:John Wiley \& Soons, 1976),33 